\title{
GAVE SYNDROME - A RARE AND MYSTERIOUS CAUSE OF GASTROINTESTINAL HEMORRHAGE IN THE ELDERLY
}

\author{
Alina Simache ${ }^{1,3}$, Alice Bălăceanu, ${ }^{1,2}$, Cornelia Voiculeț ${ }^{1,2}$, Secil Omer ${ }^{1,2}$, Ion Dina ${ }^{1,2}$, \\ Magda Ruxandra Zaharia ${ }^{1,2}$ \\ 'Spitalul Clinic de Urgență "Sfântul Ioan", București \\ 2Universitatea de Medicină și Farmacie "Carol Davila", București \\ ${ }^{3}$ Institutul Oncologic „Prof. Dr. Alexandru Trestioreanu”, București \\ Corresponding author: Alina Simache \\ E-mail: alina.simache@yahoo.com
}

\begin{abstract}
GAVE syndrome (gastric antral vascular ectasia) is a rare cause of gastrointestinal bleeding. It affects mainly the elderly. The syndrome was named "watermelon stomach" because of its typical endoscopic appearance of "watermelon stripes" observed at the gastric antral level. We present the case of an 80-year-old female patient, under iron substitution therapy for an iron deficiency anemia previously diagnosed. The woman was admitted to our hospital for non-specific symptoms, severe asthenia and postural instability. The clinical examination noted pallor of skin and sclera, without hematemesis or melena. Paraclinical tests revealed severe hypochromic microcytic anemia and hyposideremia, with a positive fecal occult blood test. Because the patient was refractory to the iron therapy, presenting with severe anemia, which required blood transfusions, we suspected a diagnosis of acute hemorrhagic gastritis. In order to reveal the source of the hemorrhage, an upper gastrointestinal endoscopy was performed, which described the typical appearance of prominent, tortuous, erythematous streaks traversing the antrum and converging toward the pylorus, creating the "watermelon stripes" pattern, with lesions that bleed easily during the biopsy process. In a different endoscopic session, the argon plasma coagulation treatment was applied, resulting in clinical and biological improvement.

Gastric antral vascular ectasia is a rare medical condition, insufficiently recognized and poorly understood, which can be treated efficiently by endoscopic means, if it is early diagnosed. Although this condition tends to be underdiagnosed at the present time, doctors may exceed their limits by acquiring a high grade of clinical suspicion.
\end{abstract}

Keywords: GAVE syndrome; watermelon stomach; gastrointestinal bleeding; iron deficiency anemia. 


\section{INTE}

\section{Rezumat}

Sindromul GAVE (ectazie vasculară gastrică antrală) este o cauză rară de hemoragie gastrointestinală, care afectează în principal vârstnicii. Sindromul a fost numit "stomac cu aspect de pepene verde", din cauza aspectului endoscopic tipic cu "dungi asemănătoare cu ale pepenelui verde" la nivelul antrului gastric.

Prezentăm cazul unei paciente în vârstă de 80 de ani, sub terapie de substituție marțială pentru anemie feriprivă diagnosticată anterior. Femeia a fost internată în spitalul nostru pentru simptome nespecifice, astenie severă și instabilitate posturală. La examenul clinic s-a observat paloare sclero-tegumentară, fără hematemeză sau melenă. Testele paraclinice au evidențiat anemie hipocromă microcitară severă și hiposideremie, cu un test pozitiv pentru sângerările oculte fecale. Deoarece pacienta era refractară la terapia cu fier, prezentând anemie severă care a necesitat transfuzii de sânge, am suspectat un diagnostic de gastrită hemoragică acută. Pentru a evidenția sursa hemoragiei, s-a efectuat endoscopie gastrointestinală superioară, care a descris aspectul tipic de dungi proeminente, sinuoase, eritematoase care traversau antrul, fiind convergente spre pilor, creând modelul de "dungi de pepene verde", cu leziuni care sângerau cu ușurință la prelevarea de biopsii. Într-o altă sesiune endoscopică s-a aplicat tratamentul de coagulare cu plasmă argon, având ca rezultat ameliorarea clinică și biologică.

Ectazia vasculară gastrică antrală este o afecțiune medicală rară, insuficient recunoscută și slab înțeleasă, care poate fi tratată eficient prin mijloace endoscopice, dacă este diagnosticată precoce. Deși această afecțiune tinde să fie subdiagnosticată în prezent, medicii pot depăși limitele actuale prin dobândirea unui grad ridicat de suspiciune clinică.

Cuvinte cheie: sindromul GAVE, stomac în "pepene verde", sângerare gastrointestinală, anemie feriprivă. 


\section{Introduction}

Gastric antral vascular ectasia (GAVE syndrome) is a rare cause of acute or chronic gastrointestinal bleeding (approximately $4 \%{ }^{(1)}$ of the total number of gastrointestinal non-variceal hemorrhages). It affects mainly the elderly, with a mean age at diagnosis of 70 years old. Although it is associated with many pathologies from the hepatic, renal or cardiac field, its etiopathology remains unsolved.

\section{Case presentation}

We present the case of an 80 year-old patient, from urban environment, retired, without toxic professional exposure or alcohol consumption, who was admitted to our hospital for: severe asthenia, postural instability, pallor of skin and sclera, symptoms with progressive aggravation. From the patient's medical history, we mention: essential arterial hypertension, dyslipidemia and iron deficiency anemia previously diagnosed, refractory to the oral iron replacement therapy. We also mention that our patient didn't present any relevant medical documents when she was admitted to our hospital.

The clinical examination noted: cardiopulmonary balanced patient, dehydration and pallor of skin and sclera, facies dolorosa, slightly distended abdomen through adipose tissue, painless spontaneously or during palpation, normal intestinal transit, dark stools (possibly in the context of the iron therapy followed by the patient in the last month), liver edge at the costal margin, the spleen was not palpable, physiological micturition, bilateral Giordano negative. At this stage, the presumptive diagnosis was: severe iron deficiency anemia refractory to the oral iron therapy, essential arterial hypertension and dyslipidemia in treatment.

Paraclinical tests revealed severe hypochromic microcytic anemia $(\mathrm{Hb}=5,5$ $\mathrm{g} / \mathrm{dL}, \mathrm{HCT}=18 \%, \mathrm{MCV}=64,5 \mathrm{fL}, \mathrm{MCH}=19,7$ $\mathrm{pg})$, with severe hyposideremia ( $5 \mathrm{ug} / \mathrm{dL})$. The fecal occult blood test was positive and the diagnostic markers of viral hepatitis $B$ and $C$ were negative (Ac. $\mathrm{HCV}, \mathrm{Ag} \mathrm{HBs,} \mathrm{AcHbc}$ ), along with the anti-Helicobacter pylori antibodies. While the examination of leukocyte and platelete morphology was normal, the erythrocytes' examination revealed iron deficiency hypochromic microcytic anemia - microcytes, policromatophil macrocytes; low poikilocytosis: ovalocytes, rare dacrocytes; moderate hypochromia. In order to reveal the source of the hemorrhage, an upper gastrointestinal endoscopy was performed, which described the typical appearance of prominent, tortuous, erythematous streaks traversing the antrum and converging towards the pylorus, creating the "watermelon stripes" pattern, with lesions that bleed easily during the biopsy process (figure 1). The esophagus (figure 2) and the duodenal bulb were normal. In a different endoscopic session, the argon plasma coagulation treatment was applied under anesthesia for approximately $80 \%$ of the GAVE lesions (figure 3 ), the gastroenterologist suggesting the continuation of the plasma coagulation treatment in a following endoscopic session. The tissue samples obtained through biopsy were sent for histopathological examination, which confirmed the specific microscopic appearance of the gastric antral vascular ectasia (fibrin microthrombi and the fibromuscular hyperplasia of the lamina propria). On the day of the discharge, the patient's family provided the medical documents from the previous hospital 


\section{INTERNAL}

\section{Clinical cases}

admission that had taken place approximately three months before the admission to our clinic. According to the patient's medical documents, the previous hospital admission was similar, with severe iron deficiency anemia, which required blood transfusions $(\mathrm{Hb}=5,8 \mathrm{~g} / \mathrm{dL}$; syderemia $=7$ $\mathrm{ug} / \mathrm{dL}$ ). Oral iron replacement therapy was recommended for the patient at discharge.

During the hospitalization in our clinic, the patient received intravenous fluid therapy to maintain the hydroelectrolytic balance, multiple transfusions of red cell concentrates (three units), iron replacement therapy, antisecretory and gastric antacids, antihypertensive medication and hypolipidemic agents. The patient was discharged in a good condition, with clinical and biological improvement and the following recommendations: specific diet, proton pump inhibitor for a month, until the gastroenterological reevaluation (with the completion of the endoscopic treatment and the reevaluation of the therapeutic scheme), oral iron replacement therapy and the continuation of the cardiological treatment.

The evolution of the patient was favorable, with a clinical and a paraclinical improvement $(\mathrm{Hb}=9,8 \mathrm{~g} / \mathrm{dl})$. However, the prognosis was variable, depending on the patient's therapeutic compliance necessary for the completion of the endoscopic argon plasma coagulation treatment.
Unfortunately, the follow-up was temporarily interrupted because of the patient's noncompliance. A year later, the patient was admitted again to our clinic with a similar clinical presentation and severe anemia $(\mathrm{Hb}$ $=5,3 \mathrm{~g} / \mathrm{dL}$, syderemia $=28 \mathrm{ug} / \mathrm{dL}$ ), which required blood transfusions. The argon plasma coagulation treatment was applied again and the patient was advised to respect the medical recommendations and the suggested periodic health examinations in order to improve follow-up and to prevent hemorrhage recurrence.

The case's particularity consisted in the difficulty of revealing the source of the hemorrhage in the case of an older female patient, presenting with severe iron deficiency anemia, refractory to the oral iron replacement therapy, without any previous medical records, which could have facilitated the management of the case. Moreover, because of the patient's noncompliance, the hemorrhage recurrence appeared a year after the first argon plasma coagulation session, which happens in $36 \%$ of the cases, according to the medical literature.

\section{Discussions}

Although it is considered a relatively rare cause of gastrointestinal bleeding, the gastric antral vascular ectasia represents approximately $4 \%{ }^{(1)}$ of the non-variceal 
gastrointestinal hemorrhages. The GAVE syndrome was first mentioned by Rider et al. $(1953)^{(2)}$ in a patient with severe iron deficiency anemia, being described as a type of "atrophic erosive gastritis with important veno-capillary ectasia". Thirty years later, in 1984, Jabbari et al. ${ }^{(3)}$ introduced the term "watermelon stomach" to describe the pathognomonic endoscopic appearance.

GAVE syndrome affects mainly the elderly, the mean age at diagnosis being 73 years for women and 65 years for men. Furthermore, the association of GAVE with different pathologies like cardiovascular diseases, nephropathies, hepatopathies, diabetes, connective tissue disease and hypothyroidism was noticed. Approximately $40 \%$ of the patients with GAVE associate hepatic cirrhosis, 1 in 40 patients requiring liver transplant. ${ }^{(4)}$

The ethiopathogeny of the gastric antral vascular ectasia is not completely understood. Some authors consider that this pathology is caused by the loose connection between the distal gastric mucosa and the muscularis externa, which could lead to the prolapse of the antral mucosa at the level of the pylorus, generating the specific GAVE lesions ${ }^{(5)}$. Quintero et al. suggest that the strong peristaltic movements can induce the prolapse and the lesions of the antral mucosa, with the secondary obstruction of the blood vessels, generating fibromuscular hyperplasia and vascular ectasia ${ }^{(6)}$.

Risk factors for GAVE include hypergastrinemia, the proliferation of the neuroendocrine cells and changes in the levels of PGE2 (prostaglandin E2), 5hidroxitriptamine and VIP (vasoactive intestinal peptide) ${ }^{(6)}$. These hormones were proposed after their presence was noticed at the level of the gastric mucosa's lamina propria. Their action seems to induce local vasodilation and hemorrhage ${ }^{(7)}$. Patients with gastric antral vascular estasia present frequently with severe iron deficiency anemia caused by slow, chronic blood loss. The lesions are usually painless and hematemesis or melena are rarely mentioned. Additionally, the associated symptoms include: severe asthenia, postural instability or dyspnea. Most of the patients become refractory to the oral iron replacement therapy, depending on blood transfusions.

The endoscopic appearance is pathognomonic for GAVE, with prominent, tortuous, erythematous streaks traversing the antrum and converging toward the pylorus, creating the "watermelon stripes" pattern, with lesions that bleed easily during the biopsy process. The diagnosis is based on the clinical examination of the patient and upper gastrointestinal endoscopy. Although tissue samples can be obtained through biopsy from the antral mucosa, offering typical histopathological findings (fibrin microthrombi and the fibromuscular hyperplasia of the lamina propria), this step is not necessary for the confirmation of the diagnosis.

The differential diagnosis of the GAVE syndrome, from the endoscopic perspective, included: portal hypertensive gastropathy, chronic antral gastritis, autoimmune atrophic gastritis and Dieulafoy lesions. The correct diagnosis is supported by the typical endoscopic appearance (which doesn't mention fibrin microthrombi in the case of portal hypertensive gastropathy, autoimmune gastritis or Dieulafoy lesions ${ }^{(8)}$. The portal hypertensive gastropathy affects mainly the fundus or the corpus of the stomach, with diffuse endoscopic lesions and it doesn't present fibrin microthrombi, fibromuscular hyperplasia or hyalinisation at 
the level of the lamina propria. The autoimmune atrophic gastritis doesn't have the specific endoscopic appearance of the GAVE syndrome, the capillaries are normal, without vascular ectasia and the fibrin microthrombi, fibromuscular hyperplasia or hyalinisation are absent. Regarding the Dieulafoy lesions, the vessels are dilated at the level of the lamina propria, there are no lesions at the level of the submucosa and the microthrombi are absent.

Sometimes, the GAVE syndrome cand be mistakenly interpreted as refractory hemorrhagic gastritis. In comparison with the antral gastritis, the GAVE lesions are well delimitated, with red spots around the edges, they blanch on pressure and they bleed easily during endoscopic biopsy. It is difficult to differentiate the GAVE syndrome from the severe portal hypertensive gastropathy in patients with preexisting hepatic cirrhosis. There is a great number of clinical studies which have demonstrated that portal hypertension doesn't play an important role in the development of the GAVE lesions. This conclusion is supported by the fact that there isn't a significant correlation between the degree of the vascular ectasia and the degree of the portal hypertension ${ }^{(9)}$.

The treatment of the GAVE syndrome is mainly endoscopic, including multiple therapeutic choices: band ligation, sclerotherapy or argon plasma coagulation.
The pharmacological and the surgical treatment should be taken into consideration only when the endoscopic methods fail.

Argon plasma coagulation is the most frequently used endoscopic method in the treatment of GAVE lesions at the moment. This technique uses argon to obtain a balanced distribution of the thermal energy on the surface of the gastric mucosa. The high frequency current is applied at the tissue level with strict control of the penetrance (approximately $2-3 \mathrm{~mm})^{(10)}$. The efficacy of this method is between 90$100 \%{ }^{(11)}$. The band ligation and the radiofrequency ablation are new, promising techniques, but they need additional training and they are not widely available.

Cryotherapy is a different method which can be used in the treatment of GAVE syndrome. This technique uses nitric oxide to freeze the pathological lesions at the mucosa level, causing superficial necrosis. One study on 12 patients with GAVE syndrome appreciated the efficacy of this method at $50 \%$, only half of the patients presenting complete therapeutic response ${ }^{(12)}$.

In comparison with other endoscopic methods, argon plasma coagulation is costefficient, with a good safety profile. The perforation risk is low; this complication appears in the case of very thin gastric walls ${ }^{(13)}$. The hemorrhage's recurrence after this type of endoscopic intervention appears 


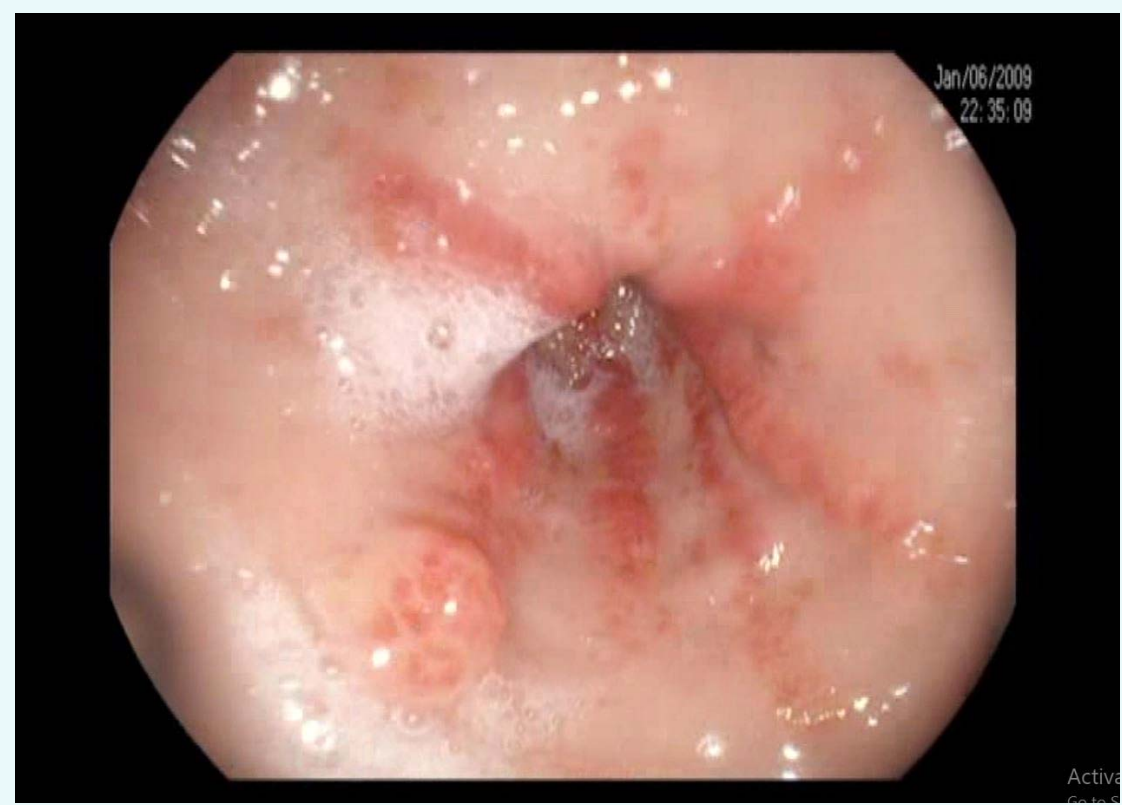

Figure 1. Typical GAVE lesions, with prominent, tortuous, erythematous streaks traversing the antrum and converging towards the pylorus

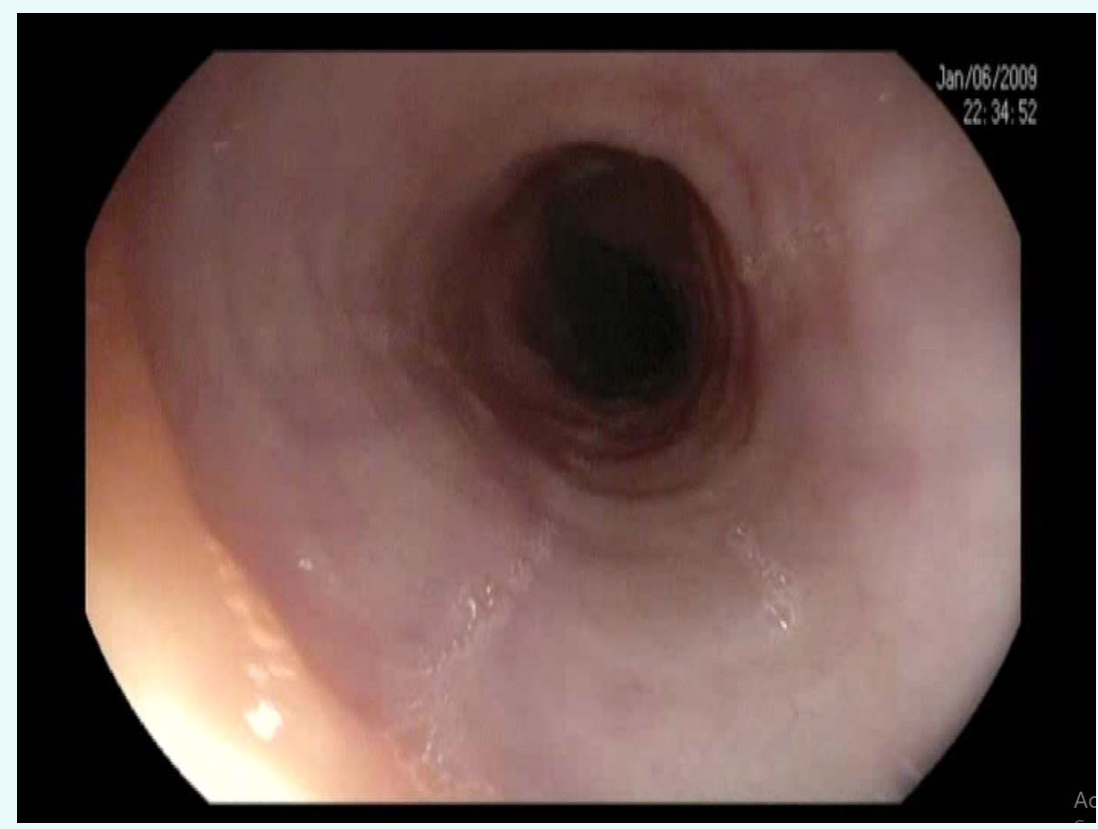

Figure 2. Normal appearance of the esophagus during upper gastrointestinal endoscopy 
INTERNAL MEDICINE

Clinical cases.

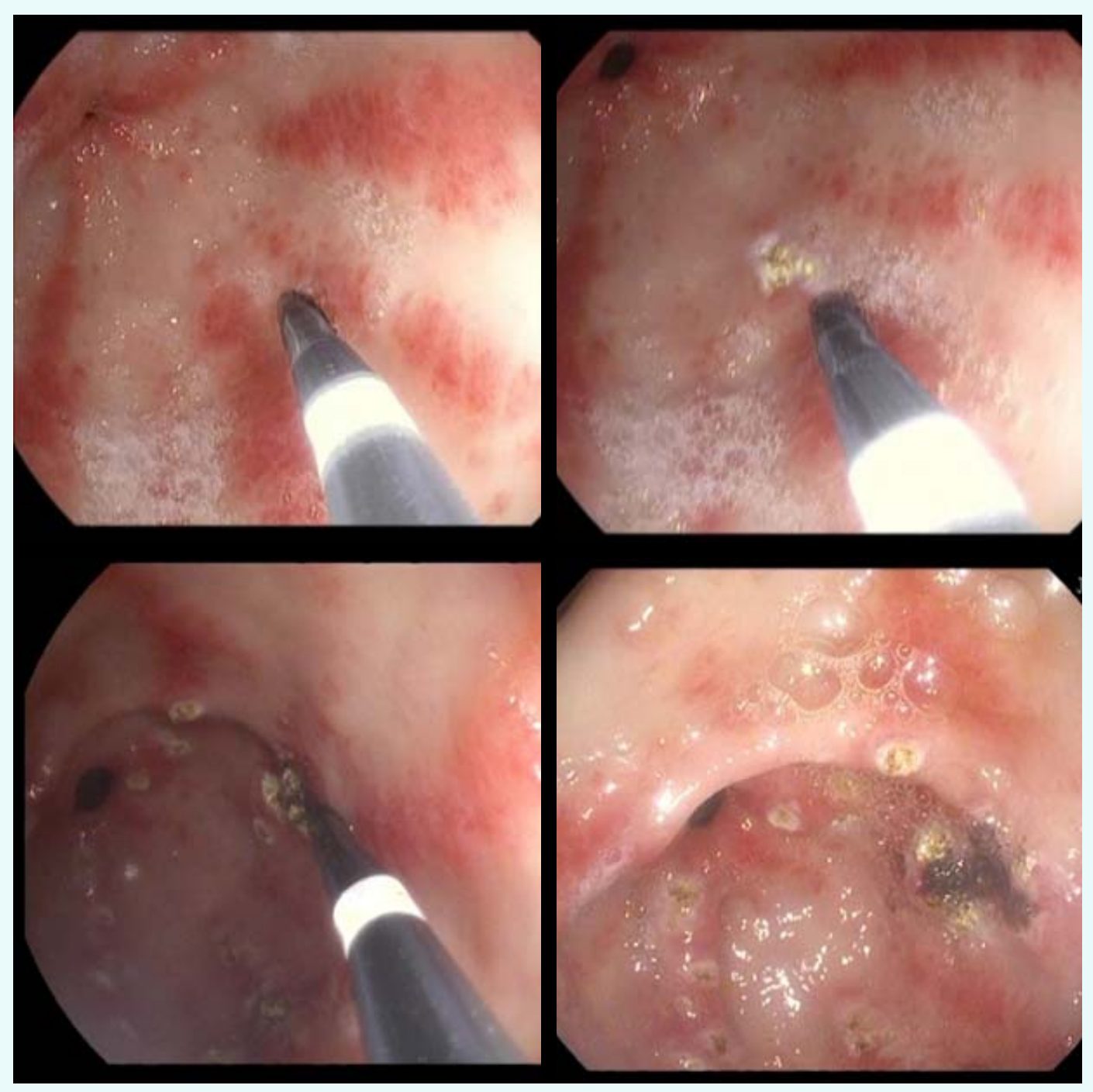

Figure 3. Argon plasma coagulation 
in $36 \%$ of the cases ${ }^{(14)}$. The pharmaceutical treatment of GAVE syndrome is not as effective as the endoscopic alternatives. Octreotide, a somatostatin analogue, seems to have a significant role in the control of the chronic hemorrhage caused by vascular abnor-malities ${ }^{(15)}$.

This effect may be induced by its capacity to inhibit neuroendocrine cells, vascular ectasia and smooth muscle cells ${ }^{(16)}$. Moreover, octreotide seems to have an antiangiogenic effect, limiting the development of new blood vessels ${ }^{(17)}$. Papachristos et al. reported the clinical improvement of patients with GAVE after the intravenous administration of cyclophosphamide ${ }^{(18)}$. Other therapeutic choices include corticosteroids, tranexamic acid, thalidomide, serotonin antagonists, but their efficacy is still questionable ${ }^{(19,20,21,22)}$.

Surgical interventions are reserved to patients who don't respond to endoscopic or pharmaceutical treatment. Gastrectomies and antrectomies are among the surgical interventions typically used. The antrectomy is most frequently used because it associates a low hemorrhage recurrence rate ${ }^{(23)}$.

\section{Conclusions}

Gastric antral vascular ectasia is a rare cause of gastrointestinal bleeding, insufficiently recognized and misunderstood, that can be treated effectively through endoscopic methods if it is diagnosed in its early stages. There is a tendency to underdiagnose the GAVE syndrome in the current medical practice.

To overcome this obstacle, we need to acquire a high grade of clinical suspicion and take into consideration this pathology in the differential diagnosis when confronted with a case of severe anemia and symptoms suggesting gastrointestinal hemorrhage.

\section{References}

1. Rider, JA; Klotz, AP; Kirsner, JB (1953). “Gastritis with veno-capillary ectasia as a source of massive gastric hemorrhage". Gastroenterology. 24 (1): 118-23.

2. Rider, JA; Klotz, AP; Kirsner, JB (1953). "Gastritis with veno-capillary ectasia as a source of massive gastric hemorrhage". Gastroenterology. 24 (1): 118-23.

3. Jabbari M, Cherry R, Lough JO, Daly DS, Kinnear DG, Goresky CA. Gastric antrovascular ectasia: the watermelon stomach. Gastroenterology 1984;87:1165.

4. Ward EM, Raimondo M, Rosser BG, et al. Prevalence and natural history of gastric antral vascular ectasia (GAVE) in patients undergoing orthoptic liver transplantation. Journal of Clinical Gastroenterology. 2004;38:898-900

5. C. J.Gostout, T. R.Viggiano, D. A. Ahlquist, K. K.Wang, M. V. Larson, and R. Balm, "The clinical and endoscopic spectrum of the watermelon stomach," Journal of Clinical Gastroenterology, vol. 15, no. 3, pp. 256-263, 1992

6. E. Quintero, J.M. Pique, J.A. Bombi et al., "Gastricmucosal vascular ectasias causing bleeding in cirrhosis: a distinct entity associated with hypergastrinemia and low serum levels of pepsinogen I," Gastroenterology, vol. 93, no. 5, pp. 1054-1061, 1987.

7. J. R. Lowes and J. Rode, "Neuroendocrine cell proliferations in gastric antral vascular ectasia," Gastroenterology, vol. 97, no. 1, pp. 207-212, 1989.

8. Gostout CJ, Viggiano TR, Ahlquist DA, Wang $K K$, Larson MV, Balm R. The clinical and endoscopic spectrum of the watermelon stomach. J Clin Gastroenterology 1992;15:256-263.

9. Payen JL, Cales $P$, Voigt JJ, Payen JL, Calès $P$, Voigt JJ, Barbe S, Pilette C, Dubuisson L, Desmorat H, Vinel JP, Kervran A, Chayvialle JA. Severe portal hypertensive gastropathy and antral vascular ectasia are distinct entities in patients with cirrhosis. Gastroenterology 1995;108:138-144.

10. Yusoff I, Brennan F, Ormonde D, Laurence B. Argon plasma coagulation for the treatment of watermelon stomach. Endoscopy. 2002;34:407-410

11. Roman S, Saurin JC, Dumortier J, et al. Tolerance and efficacy of argon plasma coagulation for controlling bleeding in patients with typical and atypical manifestations of watermelon stomach. Endoscopy. 2003;35:1024-1028

12. Cho S, Zanati S, Yong E, et al. Endoscopic cryotherapy for the management of gastric antral vascular ectasia. Gastrointestinal Endoscopy. 2008;68:895-902

13. Wahab PJ, Mulder CJ, den Hartog G, Thies JE. Argon plasma coagulation in flexible gastrointestinal endoscopy: 


\section{INTERNAL Clinical cases}

Pilot experiences. Endoscopy 1997;29:176-181

14. Jackson CS, Gerson LB. Management of gastrointestinal angiodysplastic lesions (GIADs): $A$ systematic review and meta-analysis. American Journal of Gastroenterology. 2014;109:474-483

15. Nardone G, Rocco A, Balzano T. The efficacy of octreotide therapy in chronic bleeding due to vascular abnormalities of the gastrointestinal tract. Alimentary Pharmacology \& Therapeutics. 1999;13:1429-1363

16. Li SC, Martijn C, Cui T, et al. The somatostatin analogue octreotide inhibits growth of small intestine neuroendocrine tumour cells. PloS One. 2012;7:e48411

17. Zalatnai A, Timar F. Vitro antiangiogenic effect of sandostatin (octreotide) on the proliferation of the placental vessels. Anticancer Research. 2002;22:42254227

18. D. A. Papachristos, M. Nikpour, C. Hair, and W. M. Stevens, "Intravenous cyclophosphamide as a therapeutic option for severe refractory gastric antral vascular ectasia in systemic sclerosis," Internal
Medicine Journal, vol. 45, no. 10, pp. 1077-1081, 2015.

19. Bhowmick BK. Watermelon stomach treated with oral corticosteroid. Journal of the Royal Society of Medicine. 1993;86:52

20. McCormick PA, Ooi H, Crosbie O. Tranexamic acid for severe bleeding gastric antral vascular ectasia in cirrhosis. Gut. 1998;42:750-752

21. Dunne KA, Hill J, Dillon JF. Treatment of chronic transfusion-dependent gastric antral vascular ectasia (watermelon stomach) with thalidomide. European Journal of Gastroenterology \& Hepatology. 2006;18:455456

22. Cabral JE, Pontes JM, Toste $M$, et al. Watermelon stomach: Treatment with a serotonin antagonist. American Journal of Gastroenterology. 1991;86:927928

23. Novitsky YW, Kercher KW, Czerniach DR, Litwin DE. Watermelon stomach: Pathophysiology, diagnosis, and management. Journal of Gastrointestinal Surgery. 2003;7:652-661 